Portland State University

PDXScholar

$5-24-2018$

\title{
Social New Orleans: Identity, Capital, Space
}

Jonathon G. Brearley

Portland State University

Follow this and additional works at: https://pdxscholar.library.pdx.edu/honorstheses

Let us know how access to this document benefits you.

Recommended Citation

Brearley, Jonathon G., "Social New Orleans: Identity, Capital, Space" (2018). University Honors Theses.

Paper 566.

https://doi.org/10.15760/honors.573

This Thesis is brought to you for free and open access. It has been accepted for inclusion in University Honors Theses by an authorized administrator of PDXScholar. Please contact us if we can make this document more accessible: pdxscholar@pdx.edu. 
Social New Orleans: Identity, Capital, Space

\title{
Written by:
}

Jonathon Brearley

\section{Thesis Adviser:}

Dr. Anna Goodman

\begin{abstract}
An undergraduate honors thesis submitted in partial fulfillment of the requirements for the degree of
\end{abstract}

\section{Bachelor of Science in:}

Architecture

$\&$

University Honors

Portland State University 


\begin{abstract}
:
Fundamentally, space is a social product. Social practices both create and are supported by the built environment. Urbanity is so much more than a dense array of buildings; it is the street, the sidewalks, the alleys, the parks, the people—from the houseless to the penthoused. A city is best understood through the mechanisms that produce the social capital, identity, and space of those people who occupy it. The city of New Orleans is no exception. In 2005, Hurricane Katrina displaced hundreds of thousands of residents, deeply impacting the social economy of the city. This research explicates three unique social practices in New Orleans in a case study format. Each case study situates itself in an established urban theory that describes an urban condition in social terms. The theorists applied in each study respectively are Jane Jacobs, Richard Florida, and Henri Lefebvre. Often, the city is rationalized as an immutable object that is navigated. The purpose of this thesis is to render urban spaces in New Orleans (the street, the neighborhood, and the land) as the product of social practices and the built environment, each mutually producing and defining one another.
\end{abstract}


Table of Contents

Introduction

Section 1) The Caramel Curves

Section 2) Faubourg Marigny

Section 3) Lakewood Estates

Conclusion

Composite Drawing

Bibliography 


\section{Introduction}

Social practices and conditions of urbanity mutually produce and define one another. On one hand, some urban theory rationalizes the city and its space as an immutable object. Kevin Lynch's ideas are an example of such theory rendering the city as components of a whole that can be defined concretely. On the other hand, some theory renders the urban condition as an amalgamation of social practices in dialogue with the built environment. This thesis argues that the city and conditions of urbanity are a social product through three case studies of social practices in New Orleans after Hurricane Katrina. The theorists this thesis engages are Jane Jacobs, Richard Florida, and Henri Lefebvre. Each of these theorists find a city's urban condition is produced through the activities of the people that occupy it. Section 1 applies the street, as Jane Jacobs describes it, to The Caramel Curves, a female biker gang. Section 2 applies Richard Florida's "Creative Class" to a New Orleans Gay neighborhood, the Faubourg Marigny. Lefebvre's "Politics of Space" and "The Everyday" are applied to a FEMA trailer siting conflict in a suburban development of the Algiers section in New Orleans. The city is defined in these case studies, both abstractly and concretely, through the active production of social capital, social identity, and social space.

In the last 50 years urban theory, informed by social practice and social identities, emerged as the afflictions of high modernist planning became apparent. Jane Jacobs' work in The Death and Life of Great American Cities places a city's inhabitants at the center of the urban theory diagram as a means of "attack" on the modernist dogma of the 1950s and 60s. Jacobs writes about the importance of social diversity in the success of a city: "To understand cities, we have to deal outright with combinations of mixtures of use, not separate, uses, as the essential phenomena" (Jacobs, 1961, p. 144). Richard Florida blends social identity with city economies in his book The Rise of The Creative Class. Florida argues that the successful city ought to focus its planning strategies on the desires of social identities to attract emerging economies. "This line of work further suggests the need for some conceptual refocusing and broadening to account for the location decisions of people as opposed to those of firms as sources of regional and national economic growth" (Florida, 2016, p. 1). Henri Lefebvre remarks on the limits of the modernist understanding of space as scientific and quantitative. "Space is political and ideological. It is the product literally populated with 
ideologies. There is an ideology of space. Why? Because space, which seems homogenous, which appears given in its objectivity, in its pure form, such as we determine it, is a social product" (Lefebvre, 2010, p. 171). These theories are often referenced in relation to each other. Jane Jacobs and Henri Lefebvre see space in a distinctly social sense, arguing that people are central to its creation. Jacobs's influence of Richard Florida's work can be found in their shared promotion of diversity in the urban setting and their value of social capital production. Florida and Jacobs became friends near the end of Jane Jacob's life; an indication of the proximity of Florida's theory to Jacobs' (Pederson, 2016). The component of Florida's work that is most readily related to Lefebvre's is the topic of urban economies and their influences on the conditions of urbanity (Schmid, 2012). It is the socialness of urbanity that emerged within the urban theory of the last 50 years that informs the direction of this thesis.

In the narrative of New Orleans, Katrina is central. In 2005, Hurricane Katrina displaced hundreds of thousands of residents, deeply impacting the social economy of the city. The city's recovery has been the subject of research for an exceptionally diverse range of disciplines from biologists to anthropologists. Katrina caused massive damage, leaving the city's infrastructure devastated, tens of thousands of homes ruined, and displaced over 400,000 people with many more deeply affected. (Whoriskey, 2006). As a result, the city's social scape and social economy was damaged and hence its mechanisms of producing social capital were deeply affected.

Social capital refers to networks of social relationships that are fostered through social activity. Forms of social capital range from being formal, institutional and organized, to informal, passive and unconcreted (Putman, 2001, p. 2). A population's social capital reflects several aspects within a population, including its ability to organize. Social capital is produced in space; a church, town hall, or square, or any other space that provides a population with the ability to hold events, gather and converse. Social networks can exist in many forms and types of social capital are much more readily applied in political organizing or fundraising. (Woolcock, 2001, p. 3). An educated group of people may make more money and have more time and resources to attend local meetings and build relationships; a less educated group who make less money and are forced to work harder and longer to make ends meet may have little time to formally produce 
social capital. Coupled with research that suggests institutions where formal social capital is produced often ostracize disadvantaged demographics, formal social capital can be extremely difficult to produce for certain groups (Woolcock, 2001, p. 17). This thesis finds gender, sex, class, and race as significant influencers of the kinds of social capital that groups can produce.

Urban social practice in this thesis references ideas described by Margaret Crawford and John Kaliski in their book Everyday Urbanism and refers to actions of a group performed in, and reliant upon, the built context. Urbanity is so much more than a dense array of buildings; it is the street, the sidewalks, the alleys, the parks, the people—from the houseless to the penthoused (Crawford, 2008, p.13). Crawford's Everyday Urbanist process advocates urbanism as a response to practices of urban participants (Kelbaugh, 2000, p. 286). These urban practices can be as banal as sitting in traffic, as small as thanking your bus driver, and as obscure as parkour. The dynamism of any city originates in its ability to simultaneously propagate new social practices while evolving in response to them.

The realm of urban theory has entered the realm of the social and thus is responsible for being conscious of race, gender, sexual orientation, class, and other social aspects of identity. The social practices engaged in the three following case studies occur in the public spaces of the city: the street, the neighborhood, and quasi-public undeveloped land that support unique mechanisms of producing social identity, capital, and space. Each study provides an avenue to understand social implications of the city in the context of history and culture within prevailing urban theory. Additionally, each study demonstrates a condition of the city produced by these social practices. 
Section 1) The Caramel Curves

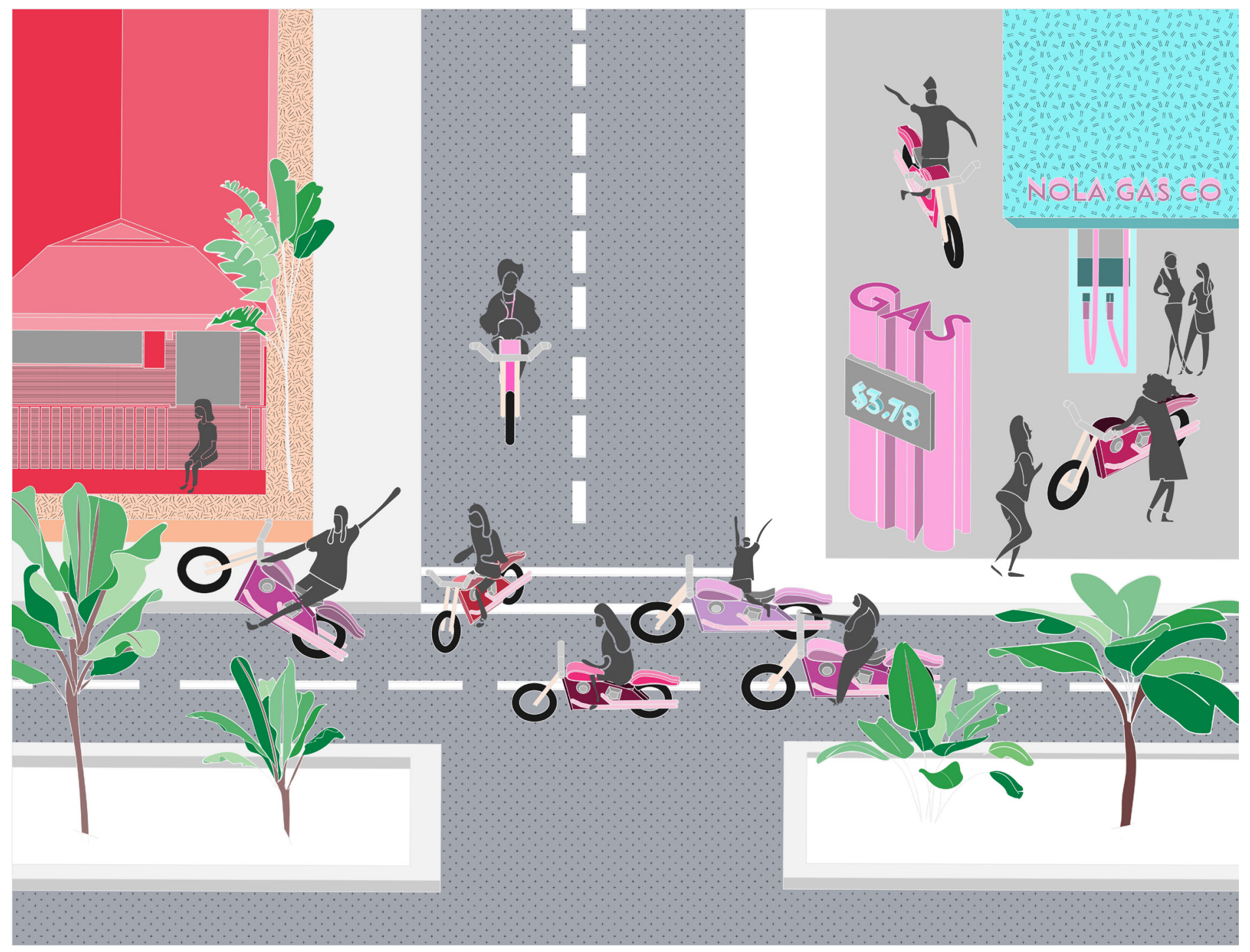


The street is no doubt a social realm, one that Jane Jacobs would argue is a space that promotes diversity and collective identity in the city. The street contributes to a sense of togetherness that builds trust amongst those who live and travel along them. The street of Jane Jacobs is created through the small interactions we share with our grocer, the barista, our friends at the local boutique. On Jacobs' street, there are things that are done, and things that are not. Trust is formed by the mutual discovery of shared values that establishes networks. Jacobs would call this network of trust social capital. New Orleans' streets are a rich site of social capital production exemplified by the Caramel Curves, an all-female biker gang in New Orleans. The biker gang began in early 2007, just before hurricane Katrina which occurred in August of the same year. Following the displacement and chaos of the hurricane the founders returned and the Caramel Curves were back. The Caramel Curves are a group whose social mechanisms are immediate, unignorable, and massively feminine. Their mechanisms of producing social capital are neither small nor gradual directly contrasting with Jane Jacobs' original vision of a successful street. Despite this, the Caramel Curves use the street and the motorcycle gang to produce strong social capital, a distinct social identity, and render the street as a social space in ways that Jacobs would not expect, but that are successful nonetheless.

Organized motorcycle gangs in New Orleans prior to Katrina were predominantly outlaw biker gang typology. Hopper writes, in his article Women in Outlaw Biker Gangs, about the masculine nature of the outlaw biker gang where women are either sex objects, positioned as a reason/cause for conflict, or as capital. The Caramel Curves, as a female biker gang, produced social capital by using the biker gang typology usually associated with displays of power and masculinity for their own displays of femininity. Katrina and the subsequent recovery mechanisms had negative effects on the production of social capital in New Orleans. The way the Caramel Curves produce social capital was extremely important in reforming a collective identity in the city.

To acknowledge the street as a significant portion of our experience of the city, let us address Kevin Lynch and Jane Jacobs. Lynch projects an abstract definition and framework through which we understand the city, one that involves a lived experience, a phenomenon, as our ability to recognize or image the city (Lynch, 1981). "Many kinds of cues are used: the visual sensations of color, shape, motion, or polarization of 
light, as well as other senses such as smell, sound, touch, kinesthesia, sense of gravity, and perhaps of electric or, magnetic fields" (Lynch, 1981, p. 357). Based on Lynch's understanding of the city, one gained through sense, he characterizes and defines the city as a network of paths, districts, nodes, edges, and landmarks. "Paths are the channels along which the observer customarily, occasionally, or potentially moves. They may be streets, walkways, transit lines, canals, railroads. For many people, these are the predominant elements in their image" (Lynch, 1981, p. 371). Contrast with Jane Jacobs' street that is a place for small social interaction. Her street promotes a sense of, though she may have used the term with chagrin, "togetherness". Jacobs saw the sidewalk as the place where a collective identity was created among the people who spend time there. Her collective identity was not immediate, in fact it gained momentum and grew with time, alongside the trust and familiarity we may feel about a place where we spend time. "The trust of a city street is formed over time from many, many little public sidewalk contacts" (Jacobs, 1961, p. 397). Cities, then, are a catalyst to produce social capital, according to Jacobs: "If self-government in the place is to work, underlying any float of population must be continuity of people who have forged neighborhood networks. These networks are a city's irreplaceable social capital" (Jacobs, 1961, p. 138). In New Orleans, the street is the site of the dynamic production of social capital, though perhaps not in the way Jane Jacobs would define it.

Helen Jarvis is the first author of the book Cities and Gender, a reader that contains a potpourri of the ways a city may be seen through the lens of gender. The most relevant section here is the argument Jarvis presents that frames the street as a male space. This is supported by multiple examples, notably research on public transport in London and Toronto that showed women disproportionately being subject to sexual harassment on public transit (Jarvis, 2011, p. 166).

These gendered differences go beyond aggregate statistics on rates of a car ownership and distances travelled to include non-representational bias, such as historical anxieties about women drivers, as bodies of 'danger', as bodies 'out of control'...The persistent existence of sexist humor and statistical evidence that attests to women's more limited access to a car. Domosh and Seager go on to observe that 'women are still outsiders at garages, auto shows, racetracks, and car dealerships--all consummate 'men's spaces' (Jarvis, 2001, p. 167). 
The male outlaw biker gang is only another contributor to Jarvis' claim of the street being a male space that subjugates and objectifies women.

The motorcycle gang is a form of social capital that has a particular relationship with the street. The motorcycle scene is relatively undocumented in New Orleans. However, several notable "outlaw" or "onepercenter" biker gangs operate in Louisiana and New Orleans: Sons of Silence, Bandidos, and the Banshees (Warren, 2015). The typology relevant to these gangs formed in the 1940s. "Outlaw" biker gangs were generally a statement of resistance against the status quo. The majority of the original outlaw biker gangs were returned servicemen from WWII who almost certainly had some form of PTSD (Dulaney, 2005). William Dulaney suggests that motorcycle riding offered relief to those servicemen who were suffering upon their return from war.

As these motorcycle gangs grew in numbers, there became an increasing amount of dissonance between the groups themselves and the American Motorcycle Association (AMA). After an event in Hollister, California wherein an AMA sanctioned motorcycle race became overrun with independent bikers who "indulged in racing their bikes through the streets of the small town and consumed massive amounts of beer" (Dulaney, 2005). A Time Magazine article published an article with photos of outlaw bikers to which the AMA responded with a denouncement of the $1 \%$ of bikers who had defamed the honor of the sport and its riders, thus "one-percenter" became a way to alienate and distant certain bikers from acceptable AMA biker culture. In the 1970s, with the return of servicemen from the Vietnam war, there was another influx of young men who gravitated towards motorcycle gangs and culture. As the gangs began to become more associated with crime, the media represented them appropriately: as criminal gangs. The gangs began to identify and own the title of One Percenter,, which had earned for themselves (Dulaney, 2005). Thus, biker gang typology was born; male motorcyclists participating in organized crime and controlling territory.

The male domination of biker groups put women in either the position of being sex objects or scapegoats for internal conflict. Columbus Hopper and Johnny Moore are professors and researchers in criminal justice. In their paper Women in Outlaw Biker Gangs, Hopper and Moore explore the roles that women fill in the biker gang. In the two generalizable agendas that motorcycle gangs exhibited, those interested in 
territory and fighting, and those motivated by money, "Women were represented in both types and they shared a remarkably similar reputation with street gang women more than 100 years later. They were considered "sex objects" and they were blamed for instigating gang wars through manipulating gang boys" (Hopper, 1990, p. 363). The established typology of the outlaw biker gang is also a mechanism of objectification and dehumanization of women. In general, women occupied one of three roles; they were either owned, their actions and relations with other members of the gang were controlled, or they belonged to the entire gang, and were usually a gift from new members to more senior members.

Women were also a form of capital for members of the gang. "If he wished to, a biker could sell his old lady to the highest bidder, and we saw this happen. When a woman was auctioned off, it was usually because a biker needed money in a hurry, such as when he wanted a part for his motorcycle or because his old lady had disappointed him. The buyer in such transactions was usually another outlaw" (Hopper, 1990, p. 372). The outlaw biker gang is a hyper masculine enterprise that seeks control and command of the street, women, and to some extent, each other. They create social capital internally, and in many cases destroy social capital externally by asserting an aggressive presence wherever they might be.

The Caramel Curves are a female biker gang in New Orleans, founded just before hurricane Katrina in 2005 and revamped two years after the storm in 2007. The gang is cited as New Orleans' first female biker gang by journalism outlets like Vice, Rideapart, and Women Riders Now as the only riding group in Louisiana. In an interview with Rideapart, one of the co-founders, Tru, said that most of the women who founded Caramel Curves started riding bikes because of their boyfriends. She knew that there were other female bikers, but none that quite fit her personality.

When I asked Tru why she wanted to start the Curves in the first place, she explained: "Most girl bikers, when we saw them, would be out, wearing all black and in leather. And don't get me wrong, they would be sexy and cute. I'm not saying that all females that ride aren't trying to be sexy, but our approach was different. We're girly girls. (Llovet, 2016).

The Caramel Curves sought to create a biker gang that operated against the status quo, establishing themselves as an alternative one percent biker gang, not necessarily outside the law. Nonetheless, the Caramel 
Curves, while being a female biker gang in a space mostly dominated by men with social capital created by and men, do not exist in opposition to the male biker gang.

The guys, they see a girl on a bike and they thinking competition like a road race, they're just like let's go. I'm not taking no mercy off of you. I'll say 'Boy, let me tell you what's gonna happen [inaudible]. Now listen to me very well, okay--I am going to swallow you whole, shit you out, and then pull you back up again, cus I will never leave you behind, okay? Don't forget that (Caramel, 2015).

The social capital that the Caramel Curves produces is a unique contribution to the biker gang community, as well as to the streets of New Orleans. In the photo “Akasha Rabul” (right), two women are pictured on Washington Ave., a street that runs through the Garden District of New Orleans (Blakely, 2017). Washington Ave. is lined

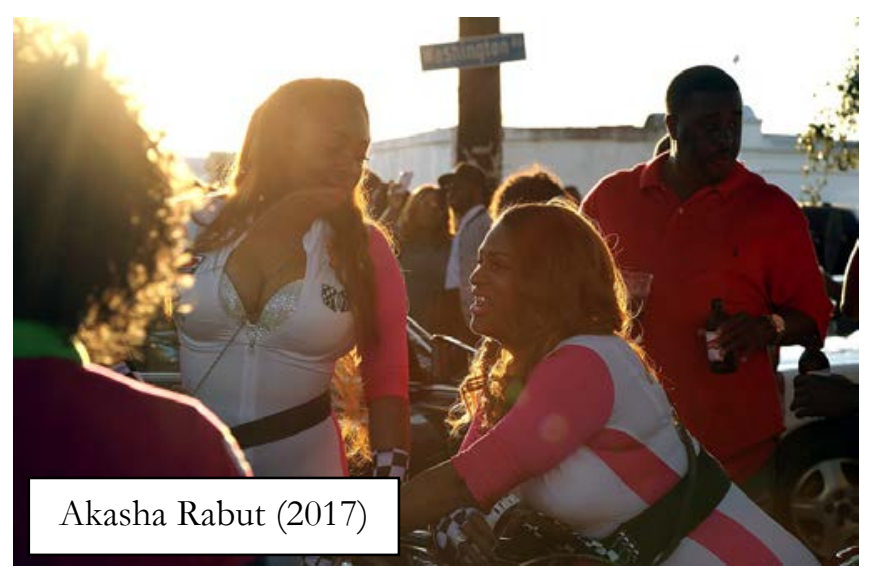
with trees, residences, and small businesses and runs from the Mississippi, in the south to Xavier University of Louisiana, in the North. The neighborhood, primarily residential, contains some of the most wellpreserved examples of the early New Orleans' mansions; it is also almost 70\% white.

Perhaps this photo offers insight into the kind of social capital the Caramel Curves are producing. They welcome local media and embrace the spotlight, in fact they seek it. Their social interactions are loud, both in terms of sound and in color: reds, pinks and bling adorn the Caramel Curves. Their presence on the street is not what Jane Jacobs would describe as the preferable mechanism of small, passive interactions that build trust and a collective identity amongst the population of New Orleans. Arguably that is exactly what the Caramel Curves are doing by creating a social capital that New Orleans, beyond the Caramel Curves, can identify with.

While the Caramel Curves are not necessarily a reaction to Katrina, the social capital they produce is extremely important as the city recovers and moves forward. Rachel Luft is a professor of anthropology and 
sociology who focuses on the intersection of race, gender, and class. Her paper Looking for Common Ground: Relief Work in Post Katrina New Orleans as an American Parable of Race and Gender explores the process of recovery after Katrina through gender and race. In discussing the relief efforts, Luft focuses on Common Ground, a coalition of nonprofits, which were mostly comprised of white, middle income people who could afford to take the time away from work. A large portion of the relief efforts revolved around physical labor gutting houses and neighborhoods.

Sam, a biracial man who was the first person to articulate the culture's patriarchy to me during the spring of 2006: "I hate to say it, but [the culture] is a consequence of the work being promoted, the hard physical labor that was unending, and thus attracted a lot more men and created a machismo atmosphere in terms of who could get the most amount of work done, and props to those who can. So the way they were doing the work alone created an environment for it" (Luft, 2008, p. 17).

The recovery effort was washed with class and race tension between the people providing aid and those receiving it. The work that was being performed mostly by men contributed to a sense of heightened masculinity which led to a large number of reported sexual assaults (Luft, 2008, p.18). The social capital being produced under the circumstances of recovery was counterproductive to a collective identity and a trust. The demographic shift in New Orleans that occurred during the decade after Katrina resulted in the ratio of the black population to the white population moving from 3:1 to 2:1 in 2000 to 2015 respectively (Lower, 2016). This is not inherently negative, however a proportional increase in the white population in New Orleans thus the production of white social capital leaves less room for the production of black social capital.

The social capital produced by Caramel Curves is an example of social capital that engages race and gender in the city, more specifically the street, a space that both Lynch and Jacobs agree is a space integral and dominant in our experience of the city. Indeed, part of the agenda of the Caramel Curves is to display their form of femininity. They are, not by apparent exclusion of other races, primarily black. The agenda of the Caramel Curves through the mechanism of the biker gang, a traditionally male typology that dominates females and territory, creates a fascinating layered social capital. By using the biker gang typology, one that 
aggressively asserts itself in the street, the Caramel Curves assert their race and gender in the streets of New Orleans through large displays of colorful smoke and fanfare.

The method of production of social capital by the Caramel Curves, is not one that Jane Jacobs ever imagined could be used as one that creates a collective identity or facilitates trust on the street. However, because of the status of social capital in New Orleans after Katrina, the method of production the Caramel Curves use is just as meaningful in New Orleans as anything Jane Jacobs may have envisioned. 


\section{Section 2) Faubourg Marigny}

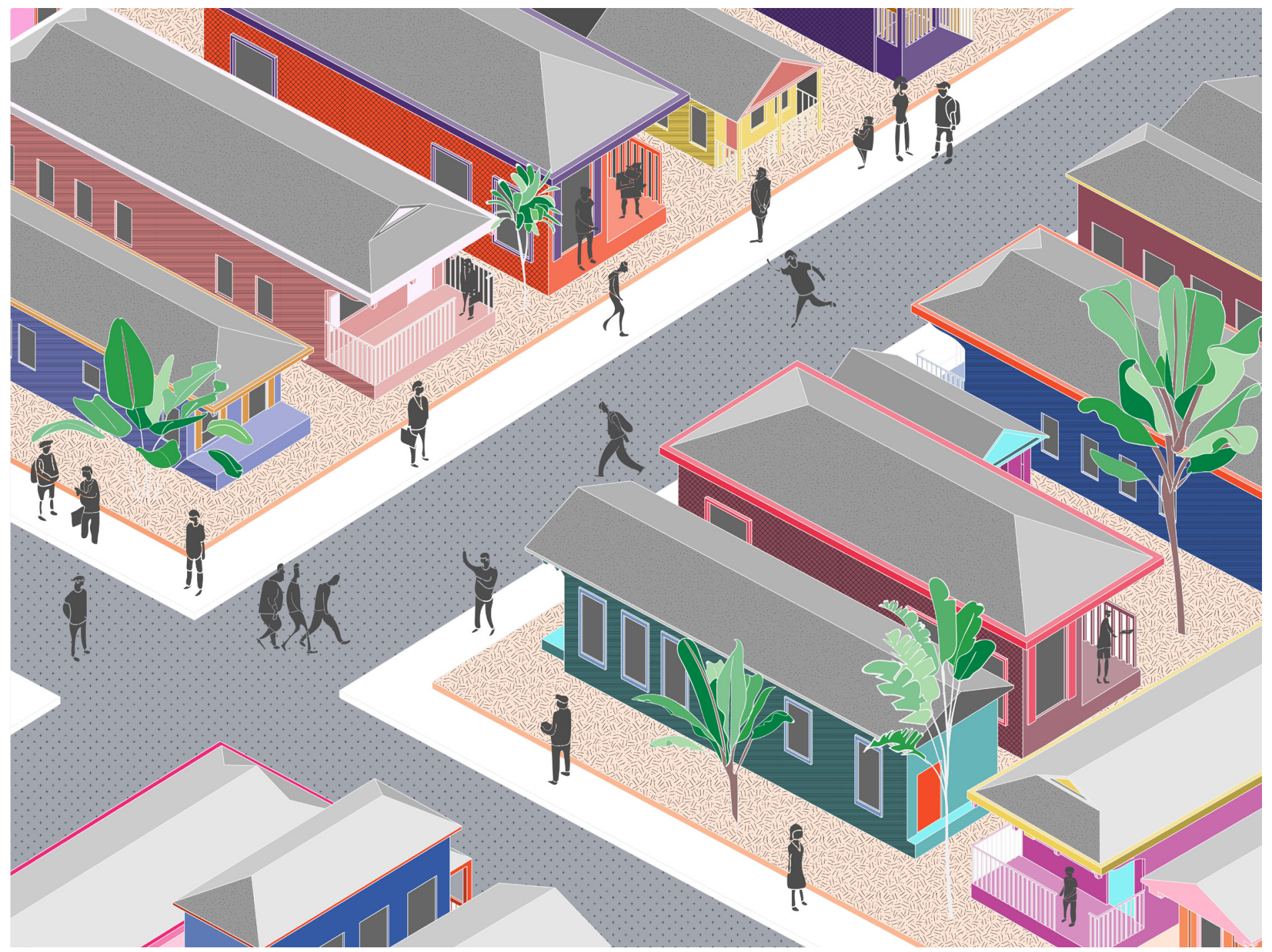


Neighborhoods and districts describe a city in a way that other factors cannot. Both geographical and defined, neighborhoods are characterful and personal. Cherished by municipalities, neighborhoods are branded to represent the whole. However, they can also be considered a blemish on the face of a metropolis. Here we examine a kind of neighborhood, the "gayborhood", a typology of neighborhood where the majority of its residents identify as gay, lesbian or queer. Neighborhoods undergo processes of influx, gentrification, or dilapidation that result in demographic shifts: the Marigny is no exception. In New Orleans, the Marigny sits at the intersection of class, sexual orientation and the queer community, race, gender, and brand. This section aims to examine these factors in the Marigny while using the Marigny as a medium for critique of Richard Florida and his concepts of the "Creative Class" and the "Gay Index". Here, the argument is made that the "Gay Index" and the "Creative Class" refers more directly to a particular gay identity, male and white, and an educated white class, respectively, often found in gayborhoods as a result of their mechanisms of formation.

The "gayborhood", or gay village, is a term used for a neighborhood which has seen its demographics shift to a majority gay, mostly white, population. An example of this, and perhaps the most well-known, is The Castro in San Francisco. The formation of gay villages occurred after WWII as personnel were being discharged, usually unfavorably, for their sexual orientation, apparent or true. In an interview with Amin Ghaziani, a sociology professor at University of British Columbia and author of There Goes the Gayborhood, Ghaziani comments: "Rather than returning home disgraced, many [gay discharged soldiers] chose to remain behind in port cities or major metropolitan areas" (Abraham, 2014). In San Francisco, the Castro, the military's discharge of gay men led to the establishment of The Castro, a "gayborhood", now one of the hubs of queer activity and activism.

The formation of these neighborhoods came at a time of extreme anti-gay crimes and rhetoric. For so many, the reality of being gay was to be subject to the possibility of physical and verbal violence. In New Orleans, a massive anti-gay massacre, a fire set under a gay lounge, killed 32 in 1973. "Churches refused to bury the victims' remains. Their deaths were mostly ignored and sometimes mocked by politicians and the media. No one was ever charged. A joke made the rounds in workplaces and was repeated on the radio: 'Where will they bury the queers? In fruit jars!”' (Stack, 2016). These anti-gay movements and hate crimes 
made the importance of a centralized space, that functioned as a hub for gay activity in a city, compulsory for creating a semblance of normality. Hence the "gayborhood" functions as a safe space, insulated from America's rejection of the queer identity and queer culture.

Richard Florida, author of Cities and the Creative Class (2004), presents a collection of essays that attempt to offer an empirical explanation of why certain cities are excelling in today's economy. His answer is what he calls the "Creative Class" which is characterized by the importance of diversity and creativity. The Creative Class is comprised of young educated liberals that value culture, art, diversity (in some senses of the term), and openness. Florida is a contemporary urban theorist and a professor of urban theory at the University of Toronto and previously taught at Carnegie Mellon University. His most recent book release The New Urban Crisis (2017) acknowledges the problems with the creative class theory, referencing displacement, gentrification, and segregation as some of the larger problems. This later book comes as a needed addition to his previous book, balancing his previous assertions about a city's path to prosperity in making an appeal to the creative class, with the harsh realities of American problems of infrastructure and housing. Somewhat ironically, and not explicitly addressed, these problems are most prevalent in those cities which Florida identified originally as model cities, embracing and creating policy and space that cater to the Creative Class. Unfortunately, this amendment comes too late, at a moment in urban planning and policy making where the notion of the Creative Class has already been engaged.

Early critiques of Florida made the observations long before Florida acknowledged them. Steven Malanga, a contributing editor of City Journal and Manhattan Institute fellow, offers a critique of Florida's work focusing on cities' movement toward producing culture to attract a creative class, branding themselves and making legislative changes that would influence an influx of creative class members in the name of economic prosperity. "Florida tells policymakers, they must reach out to the creative class, whose interests are different from those of the buttoned-down families that cities traditionally try to attract through good schools and low taxes. The new creative class craves a vibrant nightlife, outdoor sports facilities, and neighborhoods vibrant with street performers, unique shops, and chic cafés” (Malanga, 2017). Malanga argues that as a result of a municipality's investment in rejuvenating their city centers with the intention of attracting the creative 
class, important civic and infrastructural projects get left by the wayside. Steven Kratke, the chair of the Economic and Social Geography department at European University Viadrina, Frankfurt, offers a critique of Florida. In the same vein as Malanga, he uses regions in Germany as a case study. His findings suggest that the presence of the creative class in regions is not an indicator of economic success. "On the basis of the foregoing analysis, we can emphasize that there is no justification for urban restructuring measures in favor of certain functional elites of the neoliberal model of society"(Kratke, 2010). The creative class is by no means the solution for cities in a period of economic downturn and thus the investment in the attraction of the creative class should be considered thoughtfully and the adoption of new urban theory should not be done frivolously.

The "Gay Index" is one of Richard Florida's attempts to quantify the characteristics that make up the creative class which brings prosperity and growth. The creation of the "Gay Index" comes from Florida looking at the top ten performing cities, in which he has identified the presence of the creative class, and in these cities a high rate of individuals who identify as gay are present.

There are several reasons why the Gay Index is a good measure for diversity. As a group, gays have been subject to a particularly high level of discrimination. Attempts by gays to integrate into the mainstream of society have met substantial opposition. To some extent, homosexuality represents the last frontier of diversity in our society, and thus a place that welcomes the gay community welcomes all kinds of people (Florida, 2008), p. 13).

Florida argues then that the presence of queer individuals in a locus indicates an openness and inclusivity, thus the creative class is either comprised of open, diverse people or, the creative class is drawn to places that are open and diverse, perhaps both. In other words, a high population of gay people indicates a place that is open and diverse, making it attractive to the creative class.

According to a Gallup poll from 2012, in terms of percentage, white people are less likely to identify as gay, $3.2 \%$, vs $4.6 \%$ of the black population and $4.0 \%$ of the Hispanic population. Interestingly, most of the central gay neighborhoods in the country are overwhelmingly white, however (Gallup, 2012). According to City Data, the Marigny neighborhood is majority white (over 85\%), the same for the Castro district in San 
Francisco and the Thornton Park neighborhood in Orlando, all recognized gayborhoods. (Louisiana, n.d.). The gayborhood, then, is not necessarily representative of American race and gender demographics, let alone race and gender demographics of New Orleans; so, where are the non-white gays. D’Ooge notes that a large population of lesbians of color lived in Mid-City, an area that was devastated by the levee failure caused by Katrina. The intersection of Florida's Gay Index and the Creative Class lies in the gayborhood with its music, food, and culture. When considering the racialized gay identity and this intersection of gayborhood and the "Gay Index", I would argue that the true relationship between the creative class and the queer community lies with the white-male gay identity and not the queer population in general.

Marigny Faubourg, the largest and most prominent gay village in New Orleans, formed in parallel with The Castro, as a similar influx of gay middle class white men sought a space in which they could cultivate their gay identity without persecution. Lawrence Knopp, now a professor of geography at the University of Iowa, wrote his doctoral dissertation on the gentrification that occurred in Marigny Faubourg as it transitioned to a gay majority neighborhood. During the 1960s and 1970s the Faubourg Marigny, along with the continental US underwent a decline in its industrial economy and growth of white collar jobs. The resulting white flight, sent its urban centers into decline as whites moved to the suburbs due to an influx of minorities into the inner city (Semuels, 2015). Urban neighborhoods were devalued and primed for demographic turnover.

Single and divorced people, young childless couples and gay and lesbian people, many of whom were just starting out in life or recently starting over, frequently found themselves with downtown jobs and little possibility of affording or even desiring to live in the suburbs...the suburbs were clearly not structured, socially or architecturally, for them... The San Francisco experience demonstrates a qualitative difference between gay and non-gay gentrification. Gay gentrifiers, he [Manuel Castells, author of The City and the Grassroots] argues, were "moral refugees" who migrated to San Francisco during the 1970s and 'paid for their identity' by making enormous financial and personal sacrifices in order to survive" (Knopp, 1990, p. 19-20). 
Castells does not elaborate on these sacrifices; however, one can imagine a personal sacrifice in the form of losing contact with anti-gay friends and family. Financially it would be more burdensome to live in a coastal city than living in rural America where the cost of living is considerably lower. However, in rural America it would be much more difficult to establish a gay identity.

Race and sex become an important factor in the conversation of queerness, especially in the conversation of gayborhoods, even more especially in New Orleans. The formation of gay villages in the US was essentially a white male phenomenon. Knopp explains this through the shifting labor economy, moving away from industry, moving toward white-collar jobs that were filled by the white educated middle class, comprised in a large part by white men. In New Orleans, many of these men were employed by the newly opened Louisiana State University. (Knopp, 1990). Knopp's explanation makes sense until the demographic makeup of New Orleans in the 1970s is considered: this period was the turning point of New Orleans' population from growth to decline and, significantly, the movement towards a majority black city (Bankston, 2010). The influx of white people with a higher level of education into the Marigny are the seeds of Richard Florida's Creative Class.

Queerness was not only a gendered status, in this case male, but a racial status as well. To be gay in New Orleans was to be white and male. Mae Henderson and Patrick Johnson's book, Black Queer Studies: A Critical Anthology, a book published in 2007, addresses Knopp's research, conducted in the late 1980s. Johnson researches black gender and sexuality as a professor at Northeastern University. He attended Louisiana State University and grew up in New Orleans. Mae Henderson is a professor of English at the University of North Carolina and has edited several books in the black studies discourse. Black Queer Studies is well positioned to offer a valid critique of Knopp's work. Johnson's chapters are supportive and complimentary of Knopp's work, calling it "rigorous and innovative" as well as "exacting in [his] precision and also highly engaging". Henderson criticizes Knopp's ability to engage race and homosexuality (Henderson, 2007, p.231).

An important observation made by Johnson is the racial hiring preference of Louisiana State University faculty; which was exclusively white. 
Knopp does not identify them racially, but at the time whiteness was implicit criterion for employment at UNO [University of New Orleans, formerly Louisiana State University], which was founded, during the last days of legalized segregation in 1958, as Louisiana State University at New Orleans. Until the late 1980s, most black professionals in higher education worked at one of the three historically black universities in the city--Dillard University, Xavier University, and Southern University of New Orleans--rather than UNO. This fact of employment segregation is important for Knopp to consider because informal networks were to play a crucial role in the gentrification of the Marigny. (Henderson, 2007, p. 232).

Thus, the concentration of white men in the Marigny, geographically near the university, was also influenced by the jobs that preferred them, along with other informal mechanisms.

Architectural preservation was one of the major drivers in the gentrification and formation of the gayborhood in Faubourg Marigny, largely because an architect whose name is unknown, also white and gay, had made a name for himself in The Castro, took an interest in Marigny, and created excitement within the white, gay demographic about the neighborhood. Marigny housing is constituted of

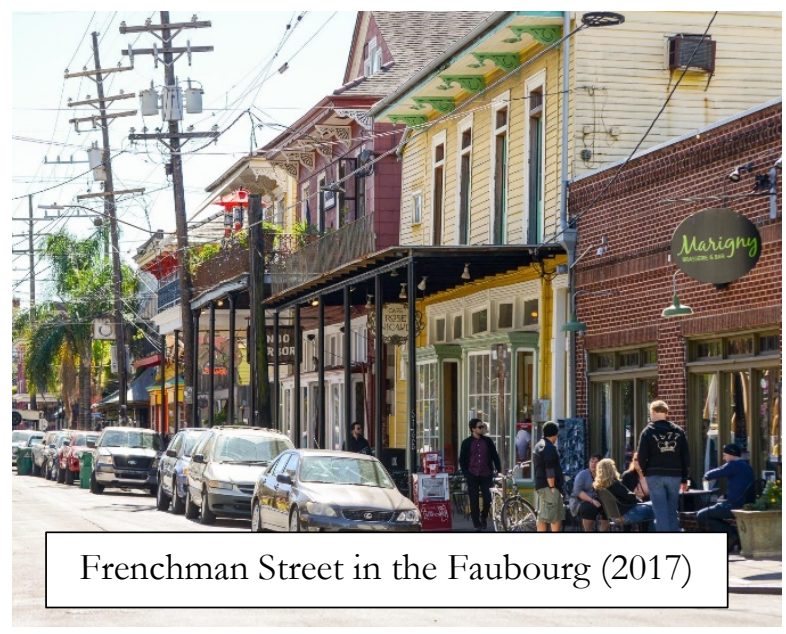
19th century French colonial homes, as well as American architecture such as shotguns, a long narrow singlestorey house with rooms leading into one another. Many of these homes were in a general state of disrepair providing an opportunity for renovation and restoration which became an exercise in ownership and control for its new residents. "Emphasizing historical preservation, white gays practiced racial and class 'tribalism' whereby they identified their interests with those of other middle- and upper-class whites" (Henderson, 2007, p. 232). The creation of the Faubourg Marigny Improvement Association in 1972, led by white-gay men, an 
enduring association that seeks to preserve the homes and character of the neighborhood, provides an excellent example of the white, gay tribalism that informed Faubourg Marigny.

The housing market in Marigny is another selective mechanism which led to the neighborhood being overwhelmingly white and gay. The initial architect who identified Marigny as a neighborhood with potential was: white and gay. Both Johnson and Knopp write about one real estate firm in the Marigny area with over 50 agents: basically, all of whom were white and gay, thereby creating housing opportunities for white gay men. Financing came easily, the houses were relatively inexpensive and their white, male, middle classness meant better, safer loans sanctioned by the FHA (Henderson, 2007, p. 234). The FHA actively discriminated against black people, making it nearly impossible for a black person to buy a home in area categorized as white and "desirable", what the Marigny was slowly becoming, citing the maintenance of house price increase as justification for racial segregation. The gayborhood as racialized and gender specific, then, is a piece of a larger phenomenon concerning the queer identity in historic white hostility towards African Americans and blacks.

The black male was seen as ultra-masculine and the wrongful understanding of what constituted a gay man excluded a black male from perceived gayness. A college football coach remembers a star player he recruited out of high school: "I found out in the middle of the season that he, uh you know, he liked guys...I mean he was a Black kid, I didn't even know they had them that way" (Henderson, 2007, p. 234). Black gayness in the media and narratives of the 1960s and 70s was trivialized and used as a means of creating inauthenticity in black characters, for the same reasons the football coach never even thought his half black athlete could be gay. Henderson outlines several accounts of white narratives, where a black gay character is an impostor or fraudulent character. "this controlling image of black gay men, which is produced by straights and gays, provides ideological support for the exclusion of black gay men from full participation in queer cultures" (Henderson, 2007, p. 239). White separatism extends to gayness in a similar way that white separatism plagues housing and businesses. 
Beyond a white, gay separatist attitude, gay culture, now decidedly white, also made itself structurally inaccessible for black men. By finding its roots in the white, middle class, male culture, a historical purveyor of racial conflict, gayness was defined as such, alienating black men in concrete and material ways.

Brian Freeman, a member of the Pomo Afro Homo, echoes Riggs's remarks in the 1997 documentary The Castro. Freeman recalls being surprised and shocked repeatedly by the overwhelming presence of white men when he moved into the district. Not only were all of the men white, but their prominent attire, which became known as "the clone look," aped the white working-class male (Henderson, 2007, p. 240).

Gayness had defined itself by race and class. Middle class white men in the 70s were an invulnerable demographic which allowed them to cultivate a gay identity in an America filled with anti-gay sentiment. The middle classness of this emerging gay culture created an opportunity for the creation of gay space in the form of gay villages and gayborhoods. The prevalence of white middle-class gayness and the space that they occupied, the black gay narratives of white discourse, and governmental systematic racial discrimination, led to an implicit whiteness associated with gayness.

The privileges embedded in the Marigny gayborhood allowed for the production of social capital that precluded those of other race and gender identities. Katrina was a devastating event in New Orleans: with $80 \%$ of the city flooded, many of its residents were evacuated, and social groups were fractured. In several ways, the hurricane highlighted existing inequalities that existed in New Orleans, an example of which can be found in Faubourg Marigny. The Marigny's location was not devastated, but certainly damaged. Many residents from the Marigny were returning to their homes even when the state recommended they did not. With unreliable utilities and no electricity, Jason DeRose of NPR reported scenes from the neighborhood. "Jim Grigsby, his boyfriend, and their four Pekingese dogs are just returning home. During Hurricane Katrina, they fled to Arkansas and then Missouri, all packed into a gold PT Cruiser. Grigsby says now that they've come back, they're prepared to ride out any more storms this hurricane season" (DeRose, 2005). Similar stories from other reports suggest that the Marigny residents were among the first to return. Otis Fennell, perhaps one of the more publicly recognized Marigny residents, owns an LGBT bookstore-Faubourg 
Marigny Art and Books. "Fennell pointed out to EDGE the city's LGBT residents were among the first people to return to New Orleans after the storm. He conceded a lack of affordable housing; access to adequate (and even basic) health care and more recently the recession...” (Lavers, 2009). Before Katrina, Faubourg Marigny already played an important role in the New Orleans's economy and gay community. Afterwards, though, the Marigny became even more central, especially because it was among one of the first places to recover after the storm.

The effort to rebrand New Orleans began almost immediately after the hurricane with Mayor Ray Nagin at the forefront of the effort. The French Quarter and the Marigny were among the first neighborhoods to recover: the hub of the night life, food, and music. "The main goals of urban branding are to reimagine a city, forge place-based identities, and control consumer impressions and understandings of a particular locale" (Gotham, 2007). In New Orleans vulnerable state rebuilding, urban branders and tourism professions had significant influence over the city. As it rebuilt, the New Orleans queer "brand" was an important pillar of New Orleans tourism revenue and would prove to be even more important in the rebranding process.

It has been vital to reassure tourists that the gay parts of New Orleans are unaffected and open for the carefree, good time that has traditionally been associated with the city. This emphasis has resulted in focusing on the unaffected traditionally gay male neighborhoods such as the French Quarter while rendering invisible the suffering of LGBT New Orleanians living elsewhere, consisting predominantly of lesbians and African Americans (D’Ooge, 2008, p. 23).

New Orleans' queer tourism efforts began to focus predominantly on the white, gay, male neighborhoods. Thus, the brand of Gay New Orleans was represented by the Marigny, reinforcing the whiteness and maleness in the gay community. D'Ooge notes that this focus of gay branding “plays a role in misrepresenting the hardships that queer and transgender women of New Orleans face" (D'Ooge, 2008, p. 23). According to Gotham, for rebranding to be successful, residents must identify with the brand being created to be successful. The way that the queer rebranding of New Orleans ostracizes the queer community outside of the 
white, male, queer identity puts New Orleans in a vulnerable position between its reliance on tourism and its relationship with its non-white residents, of which there are many. This leads to a single group, in this case majority white, gay males, representing the queer community in New Orleans, presenting an opportunity to reimagine the city's brand, and double down on attracting the creative class.

New Orleans' rebranding makes clear nods to the Creative Class. With an increased focus on nightlife, the historic French Quarter, music, and food makes New Orleans a prime destination for members of the Creative Class: the emphasis on queer culture makes it even more attractive. This focus on the gay, white culture, which can generally be found in the gayborhoods, contributes to the shifting racial demographics of New Orleans. Addressed in a few of the critiques of the Creative Class theory, New Orleans has focused resources on providing for tourism and postponing the rebuilding of important infrastructure and civic services. An example of this is New Orleans's much criticized investment in replacing historic rail cars over investing in a functional bus system that services disadvantaged citizens (Jaffe, 2015). The pursuit of attracting the Creative Class can lead to a fractured, segregated and misrepresented populous.

New Orleans is an important city in the queer community. Despite its aggressive branding of the white, male, queer identity, New Orleans is a place where a queer identity is celebrated and embraced. The complicated dynamics of the gay identity and the creation of the gay identity in American history, however, have led to the "Gay Index" as a product of the white, male gayborhood. As post-Katrina New Orleans promotes the gay identity found in the Marigny they simultaneously promote an exclusive gay identity of the city that actively alienates many of its residents. 


\section{Section 3) Lakewood Estates}

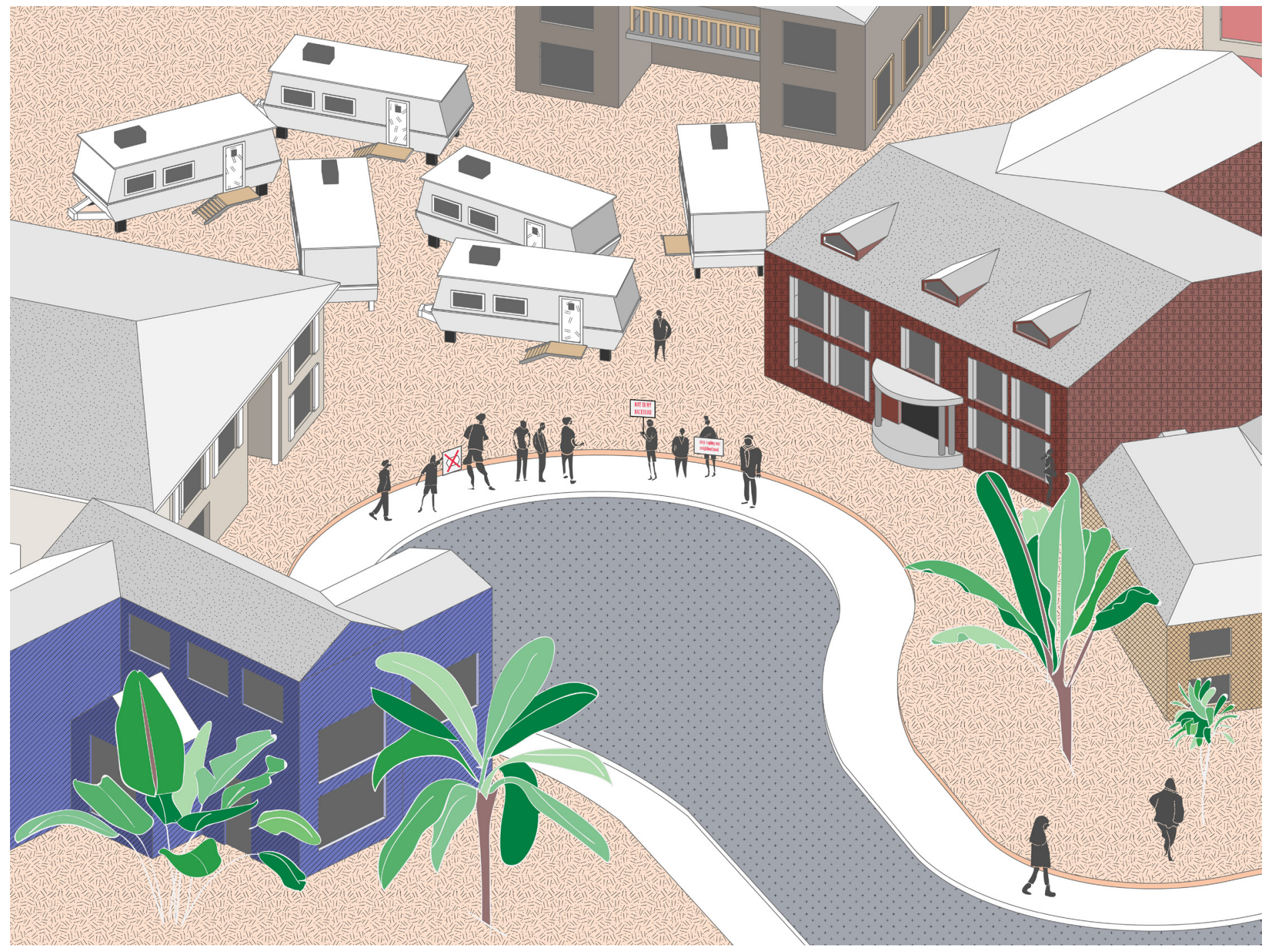


This section is not defined by the critique of theory but the application of theory, in this case the work of Henri Lefebvre, with the hope of gleaning insight and perspective on a conflict that arose in the Algiers section of New Orleans very soon after Katrina. Broadly, this section engages the nature of communication and its influence on social practices and urban interventions. Communication is central to the production of Space. Space is not an object but a dynamic construction of layered dialogue. Henri Lefebvre argues that space is political by explicating space as the conflated product of social practices, facts, race, gender, etc. Here we examine the construction of Space through communication, more specifically, the communication of FEMA, the city government of New Orleans, a neighborhood named Lakewood Estates, and those individuals who were displaced by Hurricane Katrina, that constructed the Space associated with the section of land identified by FEMA as a temporary housing trailer site. Inextricably related to the communication of respective entities is their social capital and their mechanisms of social capital production which are closely related to class, race, gender, education, etc. To understand the construction of this Space via communication, we must identify the stakeholders' methods of communication and their motives as they relate to each other and to the land itself. This section explores stakeholders' methods of communication and argues that the technocratic and rational communication methods of FEMA acted as a common communication method among stakeholders which resulted in a conversation rooted in emotion and irrational, made opaque by a mask of rationale. The Lefebvrian idea of the Everyday, specifically the notion of a common denominator, provides a lens to understand the incongruities of stakeholder communication. The purpose of this section is to apply Lefebvrian thoughts on Space and the Everyday as a means of understanding the problem of how limited communication produced Space in Algiers.

\section{The Everyday}

The Everyday is embodied in banality, the constant, and the lack of surprise. Lefebvre writes: "The Everyday is situated at the intersection of two modes of repetition: the cyclical, which dominates in nature, and the linear, which dominates in processes known as 'rational." (Lefebvre [B] 10). The Everyday is most readily understood, paradoxically, as the product of consumption. It encompasses the social nature of consumption, but also the individualism fostered in commodity-based society. Lefebvre defines the Everyday 
as a product of capitalism. It unifies culture and flattens it, unifying society and people in its comfort and expectedness. "[Organized passivity] means, in leisure activities, the passivity of the spectator faced with images and landscapes, in the workplace, it means passivity when faced with decisions in which the worker takes no part, in private life, it means the imposition of consumption" (Lefebvre, 1987, p. 10). The enduring nature of the Everyday is not easily broken or changed because of its ingrained repetition and resulting passivity. Our attachment to the Everyday is exposed when it is threatened. The impositions and passivities that define an Everyday are not necessarily perceived. Everydays create a sense of stability, privateness, individualism, comfort, and expectedness, each quietly insidious.

The Conflict

After Hurricane Katrina, many were displaced by flooding and other consequences of the storm. FEMA, Federal Emergency Management Agency, began exploring sites to place temporary housing trailers. One site in Lakewood Estates, a gated community, garnered a large amount of attention when the residents of the neighborhood protested the placement of trailers in their neighborhood in such proximity to their homes. The protest mainly took the form of an occupation of the site and blocking the roadway. Residents had organized, apparent by the sizable turnout and their prepared signs.

The proposed trailer site in the Algiers section of New Orleans in the Lakewood Estates neighborhood sits at the confluence of technocracy, politics, racism, aestheticism, and reductive communication. Post-Katrina recovery efforts positioned this piece of land at an intersection of stakeholders: The Federal Emergency Management Agency (FEMA), New Orleans' city government with Mayor Nagin as its representative, displaced citizens, and residents of the Algiers neighborhood. 


\section{Communication, Social Capital, and Common Denominators}

The Everyday in Lakewood is as might be expected of a white suburb; private, consumptive, domestic, all reinforced by repetition that results in passiveness. (Lefebvre, 1987, p. 7-11). The importance of the Everyday in this study is how it endured in the residents of Lakewood who were minimally affected by hurricane Katrina. Houses remained intact, possessions were not lost, cars remained in their garages. The sacredness of their Everyday became unmasked as it was threatened by a perceived assault on the aesthetic of the suburbs and the sudden insertion of a population of primarily different race and class (Nossier, 2006). The power of the Everyday was exhibited in the reaction of Lakewood as they protested the trailer site that would house over one-hundred displaced citizens in New Orleans.

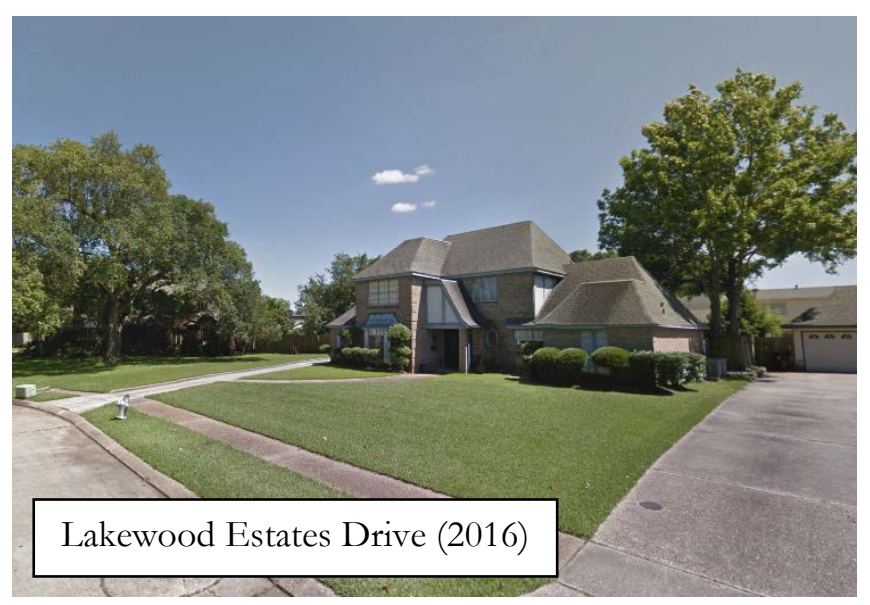

Nagin, the heart of the city's government, had significant effects on New Orleans when he entered office. In his first term the city's economy boomed, and his branding efforts gave boosts to the tourism industry. After Katrina, in the efforts of rebuilding, Nagin became the voice of the people, expressing frustration with the federal government's response. "'Don't tell me 40,000 people are coming here. They're not here. It's too doggone late,' he said. 'Now get off your asses and do something, and let's fix the biggest goddamn crisis in the history of this country"' (Pao, 2015). His priorities were aligned with the city of New Orleans, as a people, but also as a brand, an idea which motivated his actions to protect it. Additionally, Nagin was influenced by the upcoming election; his term was ending in 2006 and he was up for reelection.

Following Katrina, Mayor Nagin assembled task forces that would help rebuild the city and, he hoped, reimagine it. Nagin had less of a vision of rebuilding, but of a resurrection. Nagin saw this as an opportunity for a new New Orleans Everyday, produced through education, tourism, public services, and planning; Nagin sought to push a New Orleans brand. Planning became one of the most important aspects of 
rebuilding after Katrina, though one of the most complicated. City planning is a slow, incremental process; this situation required immediacy. "The mayor constantly contradicted, and thereby undercut, his stance on land-use planning and planning-process protocol when he spoke to groups with different agendas" (Verderber, 2009, p. 168). One of the largest sticking points of land-use and planning issues was the siting of the FEMA trailers because he didn't want trailer parks to scar the city in his attempts to rebuild it. He also needed to find housing for thousands of displaced citizens (whose vote he needed in the coming year). Nagin often found himself stuck between a rock and hard place when considering the wants and desires of various parties involved. As a planning and urban design process ensued, "an armada of FEMA trailers quietly conquered the landscape" (Verderber, 2009, p. 168). Nagin was unprepared for the residents of Lakewood's protest, exemplified by his reaction to their protest.

Nagin initially halted any further trailer installation despite having previously approved the site with FEMA. The city's internal communication was bureaucratic and hierarchical. Communication with FEMA happened in private where information was shared on a need to know basis. Public announcements, however, came from Mayor Nagin whose voice was amplified through the press. In a report from NRP, author Jeff Brady notes that Nagin was "habitually relaxed in his actions", perhaps as consequence of inefficient bureaucratic methods of decision making (Brady, 2006). In the report, Brady also notes that, as the conflict between Lakewood and the city unfolded, communication with FEMA was sparse and unpredictable, calling FEMA, at points, "puzzled” (Brady, 2006). Nagin's methods of communication were unpredictable, in private it was bureaucratic, in public he was often emotional; the two contradicted each other. Mixed messages from the City were difficult to process for FEMA which was not used to partnerships with municipal governments in the first place.

FEMA's methods of communication are governed by a hierarchical flow through which information travels vertically. The bureaucratic nature of the organization's communication leaves little room for anything else but institutional fact. As a result, points through which information flows out of the organization are narrow and tended to come on a need-to-know basis. In this case, the identification of the Lakewood site was shared and approved with the city but was not communicated to the residents simply because FEMA did not 
have a process for notification. As documented in an article for NPR by Jeff Brady, "typically, local governments give up most of their control over zoning and permitting to get as many trailers in as quickly as possible. But here, local officials want veto power over every single trailer site” (Brady, 2006). The local officials, in this case, were primarily Mayor Nagin's administration.

In a technocratic process, FEMA identified the site in Lakewood as a suitable location for a FEMA trailer site primarily for its location at a higher elevation (Aldrich, 2013). The common factor in the majority of sites that FEMA identified as suitable places for temporary housing was their elevation. Interestingly, Aldrich's research finds that most of FEMA's preferred sites were unsuccessful, and sites at lower elevations, in areas that sustained greater damage had a higher rate of installation without protest or resistance. Aldrich cites the intact organizational networks and resulting effective resistance to FEMA trailers as the reason for the failure of trailer installations on sites at higher elevations.

People of New Orleans who resided in locations and neighborhoods that were largely unaffected by Katrina were generally opposed to FEMA trailers being placed close to their neighborhoods. The residents of Lakewood were no exception. Lakewood Estates is an affluent, gated, neighborhood; while most of the Algiers district of New Orleans is Black, Lakewood Estates has an 89\% majority white resident population. The area has one of the higher rates of education with $75 \%$ of its residents having received a Post-Secondary Degree (Lakewood, 2015). This indicates a high level of organizing ability and positions them as influential voters in New Orleans. Lee citing Aldrich writes, "the dark side of community social capital was revealed when the communities with a more vibrant civic culture or with more political power were more effective at retarding FEMA trailer placements than those with less social capital” (Lee, 2007). Lakewood is a perfect example of this dark side. Their social capital, made evident by their level of education, income, and race, made Nagin acutely attuned to their desires leading to the City's quick reaction to the resident's complaints, especially because Lakewood was citing the city's poor judgement as cause for their complaints.

The residents of the Lakewood Estate's communication came in two forms: protest and votes. Their protest was peaceful and effective, though their rhetoric was violent. "FEMA, their signs proclaimed, was 
'raping' their neighborhood" (Nossiter, 2006). Their complaints used words like "illegal” and "illogical", referring to the site's lack of adherence to the city's building code. In April, as residents heard heavy machinery coming to continue work on the site, residents "formed a human and vehicular chain that pressured about twenty-five FEMA workers to leave" (Verderber, 2009). The altercation ended when police arrived and threaten to arrest the federal security guards whose job it was to protect the trailer site.

The homeowners in Lakewood Estates were central to the abandonment of the FEMA trailer site in Algiers. They were motivated by the protection of their Everyday, something they felt was being actively endangered with the introduction of FEMA trailers. The residents of Lakewood were outwardly concerned about their house prices, the litter that is associated with lower income areas, and the potential for higher crime rates consistent with NIMBY (Not In My Backyard) rhetoric (Lakewood, 2015). The residents primarily had irrational concerns, one being the aesthetics of the intervention, though this was expressed indirectly (Duncan, 2004). A second subversive narrative that motivated the residents of Lakewood was the latent classism and racism embedded in this typologically white suburb that associated the rise in crime rates, litter, and house price declines with class and race (McConahay, 1976). The residents of Lakewood had complex motives for their resistance against the FEMA trailers that combined the emotional with the rational, despite their outwardly rational concerns potentially because they knew, innately, that FEMA had no capacity to process emotional complaints.

While the Residents of Lakewood's ability to organize was left intact, the ability for those who were displaced by Katrina to organize was heavily impacted. In some cases, businesses agreed for some FEMA trailers to be located on their land under the condition their workers would be the people housed. This exemplified a similar relationship to a community's ability to produce social capital to the residents of Lakewood where the educated and well employed found themselves in positions of advantage. Thus, the displaced population essentially had no tools for establishing any means of producing social capital other than what residual social capital remained. The Everyday of the displaced residents of New Orleans was completely dismantled. Those who were displaced found themselves with few of their possessions and little 
consistency in their lives, no privacy, and an inability to act passively. The residents of Lakewood's Everyday endured, demonstrated through their ability to organize and protest.

The biggest problem for the displaced people was that they had no voice. They were rarely connected, apart from familial connections, and largely did not have any discernible method of communication. Concerning trailers and their associated issues, the media gave voice to institutional officials involved in the conflict of trailers not to the people who needed them. This resulted in rational public communication; Mike Hirsch of FEMA comments in an interview with NPR's Scott Horsley, "we want to make sure, before people move into mobile homes and travel trailers, that there are no toxic materials in the area. We want to make sure they're not in the floodplain because, unfortunately, we've had experiences over the years where we placed mobile homes inappropriately and people died as a result of subsequent storms" (Horsley, 2005). Power relationships between different stakeholders made it clear that the displaced citizens had little power, nor a means of producing social capital, a resultant of a nonexistent Everyday, which significantly impacted their ability to effect change.

FEMA, a technocratic agency, identified locations for trailer siting based on their elevation and the likeliness of that site to flood again. FEMA directly communicated with the city about locations for trailer sites and the city responded in kind, initially approving the site. The city's communication was influenced by the presence of audience, public vs private, and emotional vs. rational. On one hand Nagin made rational approvals of site based on FEMA's technocratic proposals in private but on the other, after the Lakewood community protested, Nagin made public emotional statements denouncing FEMA for actions that he authorized behind closed doors in rational conversation. "You're not going to come in and disrespect our citizens. You're just not going to do it. And if I have to shut this down and figure out a way to go borrow money to get this work done for temporary housing, we're going to do that. But we're not going to be disrespected" (Brady, 2006). Of course, Nagin was motivated by his desire for reelection which explains his oscillating use of rational and emotional communication. It might be argued that Nagin applied the two different communication methods in a rational way to manipulate his desired outcome. With the press, as a relatively autonomous body tasked with constructing narrative and motive in the most credible way, the 
residents of Lakewood, intentionally of innately, realized that the best way to communicate their irrational concerns was to mask them in rationalized arguments. The concreteness of these rationalizations made it easy for the press to report "fact" concurrent with objective descriptions of actions, a peaceful and effective process.

The site in Lakewood is a space of multiplicity constructed in language and communication. Upon the examination of motive and influencing factors, the politics of this place expose themselves. This space is social in that it was the subject of a distinct social practice, a protest, manifested in methods of communication. It is a temporal space, exemplified by the course of communication that concerned it; it was created through a series of subsequent, chronological reactions. Most importantly, this Space is interpreted and experienced in exceptionally different ways. It sits at the intersection of race, class, economy, brand, politics, gender, tourism, and Everydays. It is the diversity of stakeholders of the site and their diverse motives, communication, and nature that make this Space. I see this as the center of understanding Space as noun versus space as object.

Effectively, if this science is a science of formal space, of a spatial form, it implies a rigid logistics, and this science would consist of nothing, but the constraints placed on the contents (the people)! By contrast, if one engages in the study of what populates this form, either the needs of people or their demands; if the focus is on the content and not the "pure" form, what guarantees that the contents are going to go into this form without being subject to privations? What guarantees that the people and their needs can be inserted into this logistics without resistance? (Lefebvre, 2010, p. 169).

To FEMA, this space is object with a set of statistical descriptors that make it a location suitable for the placement of trailers. The above excerpt from Reflections on the Politics of Space describes the Lakewood conflict aptly, and even responds to Lefebvre's questions. FEMA subjected this space to privations (trailers), though ironically, these privations were an additional consequence of rationale. Not only was the space identified by technocratic means, the privations were ultimately another hyper-rationalized spatial layer. 
The trailers themselves are unaesthetic; a result of FEMA's strict and minimal guidelines given to trailer manufacturers. They were intended for short term living, weeks or even a few months. Kitchens were barely workable, especially when cooking for more than two or three. A manual from one of the trailers reads: "Remember, your trailer is not designed, nor intended, for permanent housing. Use of this product for long-term or permanent occupancy may lead to premature deterioration of structure, interior finishes, fabrics, carpeting, and drapes." Further, "Keep the temperature as reasonable cool during cold weather as possible" (Verderber, 2009, p. 170). The trailer itself was created technocratically, each the same in form, each with the same relationships to one another. "They were, without exception, configured in rows, forming, whenever possible, a matrix in plan" (Verderber, 2009, p. 174). The trailers themselves, as an object intended for occupation, fit some parts of Lefebvre's Everyday, but are incongruous with others. "Thus defined, the everyday is a product, the most general of products in an era where production engenders consumption, and where consumption is manipulated by producers: not by 'workers' [those who experience and have an Everyday], but by the managers and the owners of the means of production" (Lefebvre, 2010, p. 9). However, these trailers expose the Everyday through their inability to be veiled and disguised as individual. The act of consuming implies choice and an opportunity to define oneself through object; FEMA trailers offer neither. The banality and obvious multiplicity of the trailer is explosive when juxtaposed with the established Everyday of Lakewood.

FEMA Trailers were not intended to be a permanent relief solution. The objects themselves do not create individual identity and social relationships, such as driving the same cars, shopping at the same malls, liking the same sports teams. They do provide shelter, barely. They are a temporary solution to an immediate problem. Incongruent communication methods between a diversity of entities result in a flattened, rational conversation. The issues of the Lakewood neighborhood in Algiers were rooted in aesthetics, classism, and racism and were expressed in rational terms of house prices, crime statistics, and the legalities of the FEMA trailer park in hopes that they might be received and understood by both FEMA and the city. The complicated relationships of FEMA, Lakewood residents, and Nagin made motives almost incomprehensible at the time. Methods of communication provide a possibility of deconstructing the complicated relationships 
of these parties not only to understand the point of conflict and motives, respectively, but to understand the conflict as a process of producing Space. 


\section{Conclusion}

Capturing the socialness of urbanity presents opportunities to test, apply, and critique theory, as well as allowing the explication of that practice's implications in broader social contexts. The Caramel Curves' occupation of a masculine mechanism of control and social capital production creates their own unique social identity and influences the social street scape of New Orleans. The unusual circumstances that produced the gayborhood known as the Faubourg Marigny had a significant impact on the way the identity of New Orleans and the way the city developed. The space came to support an openly gay lifestyle which was radical for the time. In the process of formation, the gayborhood displaced a large number of people and increased the location's desirability. The Marigny's formation contributed to burgeoning, contemporary, urban theory like Richard Florida's. The intersections of these diverse groups and their respective methods of social capital production converge to produce urban space via complex mechanisms of gender, race, class, and communication.

Urban social practices are entirely unique to their own contexts and carry individual significance for their respective practitioners. Lefebvre would call these social practices temporal; they are in constant flux. Each person changes the methods of social capital production. Social capital and identity is so much more than method: it is geography, personality, history. Each of these studies calls upon the importance of defining the city in terms of its socialness. It is in the public sphere that agency is demonstrated, and mechanisms of oppressive power are confronted. For Jane Jacobs, a successful city accommodates various social functions at different times, from different people, with different intentions. While Jacob's vision of the diverse city may not have envisioned the kinds of practices like those of the Caramel Curves, she embraced divergence.

Florida's work indexes and rationalizes social practice. In doing so, he reduces the expression of queerness to a nonrepresentative singularity of the white man. Florida advocates leveraging the influence of social practices to effect urban change. Lefebvre's urban condition is rooted in the temporal and political. Space is the product of social action.

The city: tangencies, collisions, and coincidences of socialness. An opportunity of expansion within this study is to query the reflections of social identities in the individual. A web of social practices lie on the 
city map as does the map of individual practices. Members of the Caramel Curves could well have been potential recipients of a FEMA trailer in Lakewood Estates, as could a Marigny dweller. A study in the cross pollination of persons through social practices that produce urbanity would implicate the actions of individuals in the production of that urban environment. Investigating the individual provides an avenue to understand the productions of the city in terms of personality traits; narcissists, introverts, empaths, etc. What an exciting thought! 



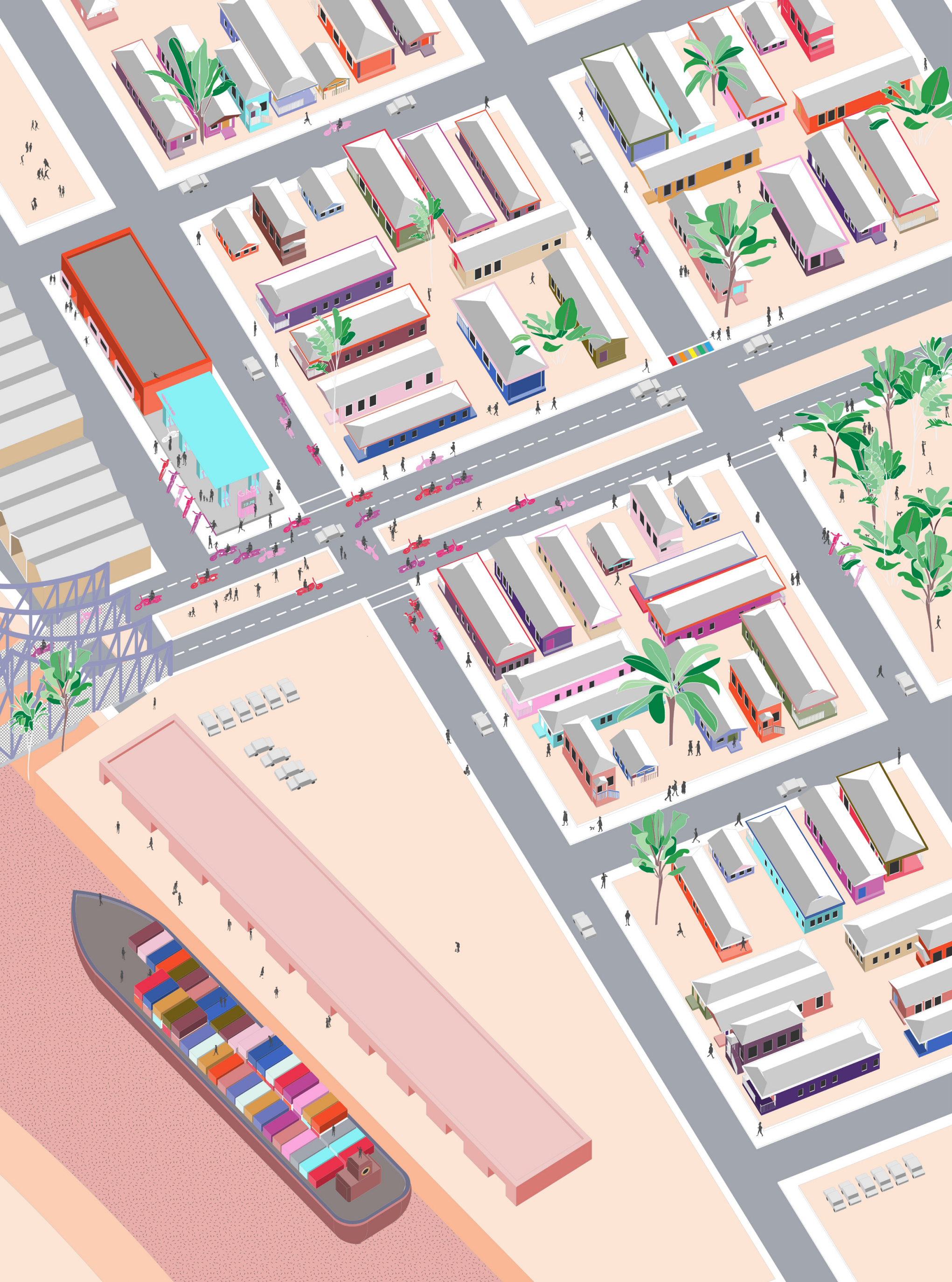




\section{Bibliography}

Introduction:

Crawford, Margaret, Leighton Chase, John Kaliski (2008). Everyday Urbanism.

Florida, Richard L (2008). Cities and the Creative Class. Retrieved from Routledge.

Jacobs, Jane (1961). The Death and Life of Great American Cities.

Kelbaugh, Douglas (2000, August). Three Paradigms: Mew Urbanism, Everyday Urbanism, Post UrbanismAn Expert From The Essential COMMON PLACE. Retrieved from SAGE Journals.

Lefebvre, Henri, et al (2010). Reflections on the Politics of Space. State, Space, World: Selected Essays. Retrieved from University of Minnesota Press.

Pedersen C. Martin (2016). Richard Florida on the Enduring Legacy of Jane Jacobs.

Putnam, Robert (2001). Social Capital: Measurement and Consequences.

Schmid, C. (2012). Henri Lefebure, the right to the city, and the new metropolitan mainstream.

Whoriskey, Peter (2006, June 7). Katrina Displaced 400,000, Study Says. Retrieved from The Washington Post.

Woodcock, Michael (2001). The Place of Social Capital in Understanding Social and Economic Outcome.

Section 1:

Akasha Rabut (2017). Pink smoke, leather mini skirts, mohawks and stilettos: Caramel Curves all-female squad put a new spin on the traditional biker gang. Retrieved from dailymail.co.uk.

Blakely, Kiri. Akasha Rabat (2017, March 15). Digital image. The Daily Mail. Pink Smoke, Leather Mini Skirts, Mohawks and Stilettos: Caramel Curves All-female Squad Put a New Spin on the Traditional Biker Gang.

Caramel Curves: New Orleans's All-Female Biker Gang (2015, Aug 21). Retrieved from YouTube. Broadly.

Dulaney, William L (2005, Nov). A Brief History of "Outlaw" Motorycle Clubs. Retrieved from IJMS. International Journal of Motorcycles Studies.

Florida, Richard, Charlotta Mellander, and Patrick Adler (2016, Dec 16). The Creative Class Paradigm." Handbook of Creative Cities "Garden District Statistical Area. Retrieved from The Data Center.

Hopper, Columbus, and Johnny Morre (1990). Women in Outlaw Biker Gangs. Retrieved from SAGE Journals 18.4, 363-87.

Jacobs, Jane (1961). The Death and Life of Great American Cities.

Jarvis, Helen, Paula Kantor, and Jonathan Cloke (2011). Cities and Gender. Retrieved from Amazon Digital Services. 
Llovet, Laura (2016, July 16). Meet the Caramel Curves Co-Founder: A Women Who Ride. Retrieved from RideApart.

Lower Garden District Statistical Area (2016, Dec 16). Retrieved from The Data Center

Luft, Rachel E (2008). Looking for Common Ground: Relief Work in Post-Katrina New Orleans as an American Parable of Race and Gender Violence. Retrieved from Project Muse 20.3 (2008): 5-31.

Lynch, Kevin (1981). A Theory of Good City Form. Retrieved from MIT Press.

Warren, Bob (2015, May 18). Biker gangs: 4 'notorious' groups, according to CNN.

Who Lives in New Orleans and Metro Parishes Now (2016 Sept 27). Retrieved from The Data Center.

Section 2:

Abraham, Ameila (2014 Sept 14). The Future of Our Gay Neighborboods. Retrieved from www.vice.com/en_us/article/5gkqm3/the-future-of-the-gay-neighborhood-438.

Bankston , Carl L (2010). New Orleans: The Long-Term Demographic Trends. Retrieved from Sociation Today Spring/Summer 2010, Volume 8, Number 1, Tulane, 2010, www.ncsociology.org/sociationtoday/v81/norleans.htm.

DeRose, Jason (2005, Sept 26). Returning Home to Faubourg Marigny. Retrieved from NPR.

D'Ooge, Charlotte (2008, Jan). Queer Katrina: Gender and Sexual Orientation Matters in the Aftermath of the Disaster. Retrieved from ResearchGate

Faubourg Marigny Improvement Association. Retrieved from www.faubourgmarigny.org/.

Florida, Richard L (2008). Cities and the Creative Class. Retrieved from Routledge.

Florida, Richard (2017). The New Urban Crisis: How Our Cities Are Increasing Inequality, Deepening Segregation, and Failing the Middle Class - and What We Can Do about It. Retrieved from Basic Books.

Frenchman Street in the Faubourg (2017). Destination 360. Retrieved from http://www.destination360.com.

Gallup, Inc (2012, Oct). Special Report: 3.4\% of U.S. Adults Identify as LGBT. Retrieved from www.gallup.com/poll/158066/special-report-adults-identify-lgbt.aspx.

Gotham, Kevin Fox (2007). (Re)Branding the Big Easy. Retrieved from Urban Affairs Review, vol. 42, no. 6, 2007, pp. 823-850.

Grabar, Henry (2017, April 11). Richard Florida Is Back With a New Theory About How to Fix Our Cities. It's a Pipe Dream. Retrieved from Slate Magazine, www.slate.com/articles/arts/books/2017/04/richard_florida_s_the_new_urban_crisis_revi ewed.html. 
Henderson, Mae, and E. Patrick. Johnson (2007). Black Queer Studies: a Critical Anthology. Retrieved from Duke Univ.

Jaffe, Eric (2015) A Troubling Review of Post-Katrina Public Transit in New Orleans. Retrieved from www.citylab.com/transportation/2015/08/a-scathing-review-of-public-transit-in-neworleans-since-katrina/401423/.

Jennings, Christopher (2015). GoNOLA Find: FAB on Frenchmen. Retrieved from GoNOLA.com gonola.com/2015/05/12/gonola-find-fab-on-frenchmen.html.

Knopp, Lawrence M (1990). Gentrification and Gay Community Development in a New Orleans Neighborbood.

Krätke,, Stefan (2010). Creative Cities and the Rise of the Dealer Class: A Critique of Richard Florida's Approach to Urban Theory. Retrieved from International Journal of Urban and Regional Research, vol. 34, no. 4, 2010, pp. 835-853., doi:10.1111/j.1468-2427.2010.00939.x.

Lavers, Michael K (2009, Sept). LGBT New Orleanians Struggle to Recover after Katrina. Retrieved from EDGE Media Network, www.edgemedianetwork.com/news///95867.

Louisiana Bigger Cities (over 6000 Residents). Retrieved from Real Estate, Housing, Schools, Residents, Crime, Pollution, Demographics and More, www.city-data.com/city/Louisiana.html.

Malanga, Steven (2016). The Curse of the Creative Class. Retrieved from City Journal, 27 Jan. 2016, www.city-journal.org/html/curse-creative-class-12491.html.

New Orleans, Louisiana. Retrieved from EPodunk - The Power of Place, www.epodunk.com/cgibin/gayInfo.php?locIndex $=3502$.

Semuels, Alana (2015, Sept 30). White Flight Never Ended. Retrieved from The Atlantic.

Stack, Liam (2016). Before Orlando Shooting, an Anti-Gay Massacre in New Orleans W as Largely Forgotten. Retrieved from The New York Times www.nytimes.com/2016/06/15/us/upstairs-loungenew-orleans-fire-orlando-gay-bar.html.

Section 3:

Aldrich, Daniel P., and Kevin Crook (2013). Taking the High Ground: FEMA Trailer Siting after Hurricane

Katrina. Retrieved from Public Administration Review, vol. 73, no. 4, 2013, pp. 613-622., doi:10.1111/puar.12071.

Brady, Jeff (2006, Apr 3). New Orleans Mayor: No More FEMA Trailers in City. Retrieved from National Public Radio.

Duncan, James S., and Nancy G. Duncan (2004). Landscapes of Privilege the Politics of the Aesthetic in an American Suburb. Retrieved from Routledge, 2004.

Foreman, Tom (2015, Nov). A Disturbing View from inside FEMA. Retrieved from CNN www.cnn.com/2005/US/09/17/katrina.response/index.html.

Lakewood Estates Drive (2016). Google Street View. Retrieved from maps.google.com 
Horsley, Scott (2005, Oct 19). Delays Plague Distribution of Trailers to Rita Homeless. Retrieved from NPR www.npr.org/templates/story/story.php?storyId $=4965917$.

(2015, April 22). Lakewood, New Orleans, Louisiana (Neighborbood). Retrieved from Statistical Atlas, Cedar Lake Ventures, statisticalatlas.com/neighborhood/Louisiana/NewOrleans/Lakewood/Educational-Attainment.

Leana, Carrie R., and Harry J. Van Buren (1999). Organizational Social Capital and Employment Practices. Retrieved from The Academy of Management Review, vol. 24, no. 3, 1999, p. 538. , doi:10.2307/259141.

Lee, Matthew R., et al (2007). The Fema Trailer Parks: Negative Perceptions And The Social Structure Of Avoidance. Retrieved from Sociological Spectrum, vol. 27, no. 6, 2007, pp. 741-766., doi:10.1080/02732170701534242.

Lefebvre, Henri, et al (2010). Reflections on the Politics of Space. State, Space, World: Selected Essays. Retrieved from University of Minnesota Press.

Lefebvre, Henri, and Christine Levich (1987). The Everyday and Everydayness. Retrieved from Yale French Studies, no. 73, 1987, p. 7., doi:10.2307/2930193.

Mcconahay, John B., and Joseph C. Hough (1976). Symbolic Racism. Journal of Social Issues, vol. 32, no. 2, 1976, pp. 23-45., doi:10.1111/j.1540-4560.1976.tb02493.x.

Nossiter, Adam (2006, Apr. 5). FEMA Trailer Park Fails to Survive Storm From Residents. Retrieved from The New York Times.

Pao, Maureen (2015). Swept Up In The Storm: Hurricane Katrina's Key Players, Then And Now. Retrieved from NPR, www.npr.org/2015/08/27/434385285/swept-up-in-the-storm-hurricanekatrinas-key-players-then-and-now.

Verderber, Stephen (2009). Delirious New Orleans: Manifesto for an Extraordinary American City. Retrieved from University of Texas Press. 